\title{
SLOVAK ROAD TRANSPORT FROM THE POINT OF VIEW OF SUSTAINABLE DEVELOPMENT
}

In spite of the various facts transport belongs to the main contaminers of environment, therefore another transport development is contingent on conditions of permanently sustained development.

The article deals with transport negative effects to the environment at present and about expected trends in the near future.

\section{Introduction}

The term "sustainable development" was implemented globally in the report by the World Environmental and Development named "Our Common Future" that was discussed by the UN General Assembly in 1987 (The Commission chaired by Harlem Brundtland - the Norwegian Prime Minister - was established by a resolution of the UN General Assembly in 1983). Under this report, sustainable development refers to such developmental methods that satisfy the present needs without harming possibilities of future generations to satisfy their own needs.

\section{Road Transport and Sustainable Development}

Transport is considered to be one of the factors significantly affecting economic development. It ensures transports of raw materials, energy resources and energy itself, goods, products and services, as well as of persons and information. From the economic aspect, it is a factor limiting economy. This is evidenced also by a fact seen in Slovakia when the transport branch contributed to GDP with $7.7 \%$ in 2003. Road transport is domineering among various types of transport and its share expressed in tkm increased from $27.51 \%$ to $37.37 \%$ in the period from 1996 to 2003 . On the other hand, transport is a source of enormous atmospheric emissions; therefore it is necessary to consider a revision of the present transport systems in the light of creating a better model and streamlining transport and transportation system management. The fundamental goal of this agenda should be the development and implementation of economically effective strategies and programmes that allow for a decrease of harmful emissions emitted by means of transport to air, as well as abatement of other harmful impacts of transport on the environment while following developmental priorities, specific local and national conditions and safety considerations.

The increase in the volume of road cargo transport supported by insufficient competition on part of railways in terms of cargo transport, and the increase in individual motorization to the detriment of mass public transport brings about the increase in fuel consumption in the field of transport, what gives a way to tendencies resulting in higher demands on the environment, including impacts on residential zones by noise and emissions of pollutants. The present period can be characterised as a turn to environmentally less friendly means of transport.

Road transport and its impacts on the environment mean not only vehicles, noise and emissions of pollutants. Let's look at the effects of road transport on sustainable development in Slovakia in broader terms.

\section{Transport Infrastructure}

It consists of roads with national importance (class I, II, III) and highways, including their sections in cities and municipalities included into the road network, and buildings required for road transport operation. The Slovak road network comprised 17, $772 \mathrm{~km}$ of roads and highways in 2003, of which highways equalled to $313 \mathrm{~km}$. Considering the relief of the terrain, the density of the

Basic Information on Transport Infrastructure

Table 1

\begin{tabular}{|c|c|c|c|c|c|c|c|c|c|c|c|}
\hline Indicator & 1993 & 1994 & 1995 & 1996 & 1997 & 1998 & 1999 & 2000 & 2001 & 2002 & 2003 \\
\hline $\begin{array}{l}\text { Length of roads } \\
\text { and highways }\end{array}$ & 17865 & 17889 & 17869 & 17867 & 17627 & 17710 & 17734 & 17737 & 17736 & 17750 & 17772 \\
\hline of which highways & 198 & 198 & 198 & 215 & 219 & 228 & 295 & 296 & 296 & 302 & 313 \\
\hline
\end{tabular}

* Juraj Cajchan ${ }^{1}$, Ol'ga Poniščiaková ${ }^{2}$, Miloš Poliak ${ }^{1}$

${ }^{1}$ Departmant of Road and Urban Transport, Faculty of Operation and Economics of Transport and Communications, University of Žilina; E-mail: Juraj.Cajchan@fpedas.utc.sk, Milos.Poliak@fpedas.utc.sk

${ }^{2}$ Departmant of Economics, Faculty of Operation and Economics of Transport and Communications, University of Žilina; E-mail:

Olga.Ponisciakova@fpedas.utc.sk 
Slovak road networks is seen as sufficient and comparable with the average in Europe. There are $3.18 \mathrm{~km}$ of roads per 1,000 inhabitants. The development of lengths of roads and highways over the period of 1993-2003 is seen in Table 1 .

\section{Machinery}

The number of vehicles used in road transport keeps increasing. Passenger cars contribute the most to this increase. In spite of this fact, the development in the number of road vehicles used on our roads has had some positive changes, too. They include:

- Increase in the number of vehicles equipped with a catalyst, high energetic efficiency and low production of pollutants in exhaust gases,

- Decrease in the number of passenger motor vehicles with a twostroke engine,

- Significant improvement in technical condition of vehicles in every category.

These are reasons why the increase in the $n$ umber of passenger cars in Slovakia is not reflected in higher emissions of pollutants, because it is the increase in ecologically more efficient vehicles rather than vehicles of obsolete generations. The issue of renewal of used up machinery in mass public transport remains to be a problem, as its machinery is depreciated up to $80 \%$ and even its simple renewal is not possible due to scarcity of financial resources.
Thee development in the number of vehicles used in road transport is shown in Table 2 .

\section{Transport Outputs in Passenger and Cargo Road Transport}

Development of passenger transportation by means of public mass road transport shows a long-term decrease in the number of transported passengers as well as in the number of total outputs (table 3). This is due to major changes in the division of transportation performances, in which individual passenger transport gets established to the detriment of any other types of mass transport.

The development in transportation outputs in cargo road transport over the period of 1993 - 2003 can be characterised as an increasing-decreasing tendency. Since 1995, it takes over the dominant position on the Slovak market from railway transport and it continues to keep this position.

\section{Fuel and Energy Consumption}

The raising tendency in fuel and energy consumption per one thousand of persons transported by road transport is affected by the increasing share of individual car transport and decreasing

\begin{tabular}{|l|r|r|r|r|r|r|r|r|r|r|r|}
\hline Number of vehicles & \multicolumn{1}{|c|}{1993} & \multicolumn{1}{c|}{1994} & \multicolumn{1}{c|}{1995} & \multicolumn{1}{c|}{1996} & \multicolumn{1}{c}{1997} & 1998 & 1999 & 2000 & 2001 & 2002 & 2003 \\
\hline Passenger & 994933 & 994046 & 1015794 & 1058425 & 1135914 & 1196109 & 1236396 & 1274244 & 1292843 & 1326891 & 1356185 \\
\hline Trucks and pick-ups & 101552 & 102470 & 102634 & 97078 & 103080 & 111081 & 115981 & 110714 & 120399 & 130334 & 142140 \\
\hline Special utility & 46121 & 45484 & 45797 & 45430 & 45376 & 43690 & 41670 & 39188 & 36082 & 34150 & 32033 \\
\hline Tractors & - & - & - & - & 600 & 1721 & 2306 & 3281 & 4994 & 6837 & 8851 \\
\hline Buses & 12655 & 12066 & 11812 & 11321 & 11235 & 11293 & 11101 & 10920 & 10649 & 10589 & 10568 \\
\hline Agricultural vehicles & 65150 & 64729 & 64536 & 62810 & 63145 & 63448 & 63493 & 64351 & 63422 & 62644 & 61690 \\
\hline Motorcycles & 81263 & 80473 & 81847 & 79479 & 81062 & 100891 & 44215 & 45647 & 46676 & 47900 & 48709 \\
\hline Trailers and semi-trailers & 167174 & 171125 & 175740 & 176246 & 182893 & 191241 & 197917 & 201269 & 206627 & 213167 & 218517 \\
\hline Others & - & - & - & - & - & - & - & 2226 & 1507 & 1306 & 1161 \\
\hline Total & 1468848 & 1470393 & 1498160 & 1530789 & 1623305 & 1719474 & 1713079 & 1751840 & 1783199 & 1833818 & 1879854 \\
\hline
\end{tabular}

Developments in Passenger Transportation and Goods Transportation in Road Transport

\begin{tabular}{|l|r|r|r|r|r|r|r|r|r|r|r|}
\hline Indicator & \multicolumn{1}{|c|}{1993} & \multicolumn{1}{c|}{1994} & \multicolumn{1}{c|}{1995} & \multicolumn{1}{c|}{1996} & \multicolumn{1}{c}{1997} & 1998 & 1999 & 2000 & 2001 & 2002 & 2003 \\
\hline $\begin{array}{l}\text { Transported persons } \\
\text { (thous.) }\end{array}$ & 825677 & 761439 & 722510 & 698256 & 667427 & 656230 & 621567 & 604249 & 564078 & 536613 & 493706 \\
\hline Outputs (mil. pers/km) & 11445 & 10574 & 11191 & 11097 & 9969 & 8840 & 7833 & 8435 & 8051 & 8236 & 7757 \\
\hline $\begin{array}{l}\text { Goods transport } \\
\text { (thousand t) }\end{array}$ & 37826 & 28465 & 32043 & 34745 & 41108 & 29889 & 39920 & 39680 & 34773 & 33035 & 30682 \\
\hline Outputs (mil. tkm) & 5464 & 4910 & 5158 & 5171 & 3779 & 4715 & 8474 & 7212 & 6557 & 6799 & 6362 \\
\hline
\end{tabular}


share of public mass transport. Consumption of liquid fuels represents the highest share, whereas the share of particulate and gaseous fuels and electricity is very low. A slight increase in motor diesel consumption can be attributed to higher demands for road cargo transport. The development in consumption of alternative fuels after 1999 shows significant positive changes in the total quantity of LPG consumed, and this can be attributed to the development of individual car transport.

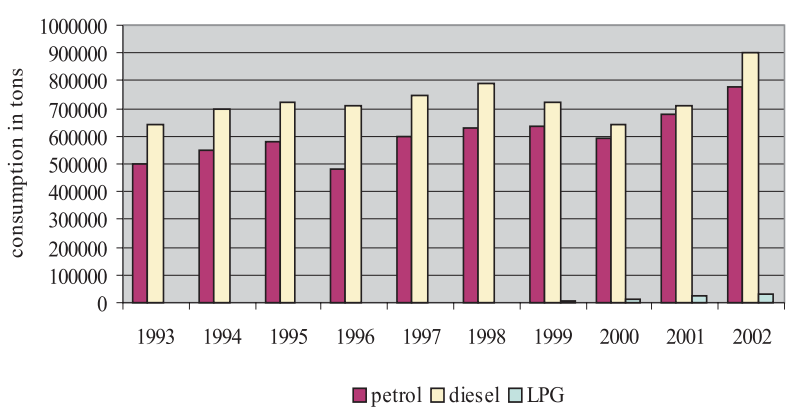

Fig. 1 Developments in total fuel consumption in road transport

\section{Emissions of Pollutants}

Development of $\mathrm{CO}_{2}$ emissions in Slovakia is still higher than the level estimated by pessimistic scenarios of the National Plan for Stabilisation and Decrease of Carbon Dioxide Emissions $\left(\mathrm{CO}_{2}\right)$ in Slovak transport for 2010 . This is a continuation of the adverse tendency that started in 2001 after the preceding positive development in $\mathrm{CO}_{2}$ production in transport witnessed in 2000 . This adverse development is determined by the increase in fuel consumption in road transport (car petrol by $5.6 \%$, motor diesel by $19.3 \%$ and LPG by $23.6 \%$ ) and higher sales of new passenger vehicles.

\section{Waste from Road Transport}

A transport waste refers to a movable item, mentioned in Annex 1 of the Act of the National Council of the Slovak Republic No. 233/2001 Coll. concerning waste and amendment of certain acts, its holder disposes, intends to dispose or is obligated to dispose in accordance with this Act or other special regulations. In most cases, this involves harmful waste (parts of decommissioned means of transport, batteries, parts of exhaust systems of motor vehicles, greasing agents, fuels and similar). Analyses of waste compositions show that waste generated by road transport includes mostly ferrous metals (65-80\%), non-ferrous metals (6-6.5\%) and tyres (4-5\%).

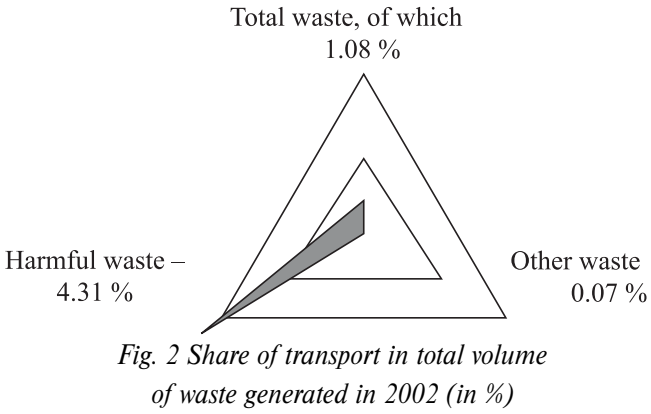

\section{Number of Accidents and Number of Casualties in Road Transport}

An accident is an event caused by a movement of a road transport vehicle resulting in casualties or injuries to health or property no matter whether this event was classified as a crime and/or offence and whether it was brought before a court or a penal commission of a Traffic Inspectorate. Despite of the optimistic decreasing development in the rate of traffic accidents over the period of 1996 to 2000, the following period failed to confirm this tendency. The number of accidents in 2001 and 2002 increased in Slovakia approximately by 10,000 and this trend can be seen also in 2003 .

\section{Conclusion}

With regard to the anticipated process of economic revival in the Slovak Republic combined with a subsequent increase in the standard of living of its inhabitants, it is necessary to take into account a continuous development of road transport in the future and related increase in fuel consumption resulting in increased production of $\mathrm{CO}_{2}$ emissions from traffic operations in Slovakia. Negative tendencies associated with such development can be kept at present within acceptable limits only by means of restrictive measures taken by governments focusing on reduction of national expenditures and increase in national revenues in the national budget, by means of increasing vital cost items of inhabitants that

Number of Accidents and Number of Casualties in Road Transport

Table 4

\begin{tabular}{|c|c|c|c|c|c|c|c|c|c|c|c|}
\hline Indicator & 1993 & 1994 & 1995 & 1996 & 1997 & 1998 & 1999 & 2000 & 2001 & 2002 & 2003 \\
\hline Number of accidents & 50159 & 53436 & 60536 & 75607 & 64854 & 57452 & 55683 & 50930 & 57258 & 57060 & 60304 \\
\hline Casualties & 584 & 633 & 660 & 615 & 788 & 818 & 647 & 626 & 614 & 610 & 645 \\
\hline Severe injuries & 2736 & 2603 & 2791 & 2691 & 2871 & 3121 & 2684 & 2205 & 2367 & 2213 & 2163 \\
\hline Minor injuries & 8682 & 8391 & 8782 & 8927 & 9676 & 9771 & 8782 & 7891 & 8472 & 8050 & 9158 \\
\hline
\end{tabular}


would have restrictive effects on developments of individual motorization and the closely associated negative development in fuel consumption. Maintaining this process within the limits of sustainability is an important challenge of the present times.
The contribution was elaborated into solution of project VEGA 1/2615/05 - Economic and qualitative changes and synergic influence on Transport and Logistics after Slovak Republic EU accession.

\section{References}

[1] Report of Slovak Republic Environment in 2003 (in Slovak), Ministerstvo životného prostredia Slovenskej republiky, KOPRINT Banská Bystrica, 2004, ISBN 80-88833-38-8

[2] Enviromagazín, magazine of Environment protection and Protection (in Slovak), 4/2004, Ministerstvo životného prostredia Slovenskej republiky, Bratislava, ISSN 1335-1877

[3] Statistical Yearbook of the Slovak Republic (in Slovak), VEDA vydavatelstvo Slovenskej akadémie vied, Bratislava, 2004, ISBN 80224-0827-1 